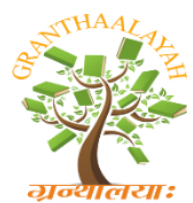

\author{
INTERNATIONAL JOURNAL OF R
GRANTHAALAYAH \\ A knowledge Repository
}

Science

\title{
ENDOGENOUS PERCEPTIONS AND MEASURES FOR AGROPASTORALISTS' ADAPTATION IN THE SAHELIAN AREA OF BURKINA FASO
}

\author{
Sanou Daouda ${ }^{1,2}$, Toe Bernadette ${ }^{2}$, Traore Almamy ${ }^{2}$, Kabore Adama ${ }^{* 2}$, Tamboura H. \\ Hamidou ${ }^{2}$, Belem A. M. Gaston ${ }^{3}$, Legma Boukari ${ }^{1}$ \\ ${ }^{1}$ Université Saint Thomas d'Aquin, FAST, Burkina Faso \\ ${ }^{2}$ Laboratoire de Biologie et de Santé Animale/DPA-INERA, Burkina Faso \\ ${ }^{3}$ Institut du Développement Rural / Université Nazi Boni, Burkina Faso
}

\begin{abstract}
The study was conducted to understand the perceptions and local adaptation strategies of rural sahelian communities in Burkina Faso to climate change on ruminant rearing practices. For this purpose, the study was carried out in the rural commune of Bani by collecting primary from semistructured interviews with 143 producers and secondary data of temperature, rainfall and their spatial and temporal evolution from 2005 to 2016. Analysis of these data reveals that $67.13 \%$ of the producers are male and $32.86 \%$ female, with an average age of $55 \pm 0.3$ years. These respondents were agropastoralists with an average of 3.5 ha of cultivated land, using traditional seeds (100\% of respondents) and improved seeds (58.7\%) and rearing local breeds of ruminants. For climate change, respondents notified an increase in temperature and a decrease in rainfall that corroborates the analysis of the meteorological data collected. The consequences of climate change on livestock farmers' resources are food insecurity, lack of pasture, drought and low animal productivity. The local adaptation strategies applied by livestock farmers are the diversification of agro-sylvo-pastoral production $(88.11 \%)$ and income-generating activities $(70 \%)$. In the study area, diversification is the strategy adopted by agro-pastoralists to ensure food security and provide income to meet the daily needs of families.
\end{abstract}

Keywords: Ruminant Livestock; Climate Change Perceptions; Endogenous Adaptation Strategies; Sahelian Area; Burkina Faso.

Cite This Article: Sanou Daouda, Toe Bernadette, Traore Almamy, Kabore Adama, Tamboura H. Hamidou, Belem A. M. Gaston, and Legma Boukari. (2019). "ENDOGENOUS PERCEPTIONS AND MEASURES FOR AGROPASTORALISTS' ADAPTATION IN THE SAHELIAN AREA OF BURKINA FASO." International Journal of Research - Granthaalayah, 7(10), 62-74. https://doi.org/10.29121/granthaalayah.v7.i10.2019.377. 


\section{Introduction}

Burkina Faso is an agro-pastoral country where livestock farming plays an essential role in the national economy, contributing more than $18 \%$ to GDP, $26 \%$ to export earnings and $12 \%$ to value added formation (MRA 2014). In addition, it is one of the main sources of income for rural populations, for which it makes a significant contribution to food security, although it is mainly practiced extensively and based essentially on the exploitation of natural pastures (Kagoné, 2004; MRA, 2006).

The national livestock population is large and estimated at more than 9.091 million cattle, 23.169 million small ruminants, 42.220 million poultry and 2.346 million pigs (MRA 2014). This Burkinabe livestock population is facing many changes in the climate environment that are at the root of their low adaptive capacity, as are Sahelian African pastoralists. These climatic disturbances increased between the 1970s and 1980s through the appearance of several successive droughts that caused significant animal mortality and ruined many agropastoralists in the Sahelian and northern Sudanese areas (MRA, 2009). At the same time, the number of farms has continued to increase as a result of population growth, drastically reducing pastoral areas. With very limited basic resources and in a context of increased competition, livestock and agro-pastoralists are finding it difficult to conduct their activities in an increasingly variable climate. Thus, climate change is seen as one of the major obstacles to pastoral production in Sahelian countries. These findings have led to numerous studies in the African Sahel to show the causal links between drought, climate change and the livelihoods of Sahelian populations through agriculture and natural resources (Hermann and Hutchinson, 2005). However, little work has been done on the knowledge of the populations directly concerned by the subject, given that the data from scientific analyses on the evolution of the environment and the understanding of local populations sometimes diverge (Fairhead and Leach, 1996).

In Burkina Faso, the perceptions, impacts and vulnerabilities as well as the different adaptation strategies implemented by the rural communities directly concerned remain largely unexplored. It is to compensate for this lack of information on the subject that this study was initiated in the Sahelian environment of the country. It aims to understand the point of view of pastoralists and agro-pastoralists in this environment on the evolution and variability of climate parameters, the impact of this evolution on their pastoral activities, the basis of their livelihood and the mechanisms they develop to cope with the effects of this climate change. Thus, the general objective of this study is to contribute to the collection of different adaptation strategies of rural communities in Burkina Faso to climate change on ruminant breeding practices. Specifically, it aims to:

- study local perceptions of climate change by ruminant herders and their impact on pastoral/agricultural resources and activities in the rural commune of Bani of the country;

- understand the local strategies developed by the pastoralists of the commune to cope with the harmful effects of climate change in their living environment.

\section{Materials and Methods}

\section{Study site}

The study was conducted in the rural commune of Bani $\left(13^{\circ} 43^{\prime} \mathrm{N}, 0^{\circ} 11^{\prime} \mathrm{O}\right)$ located in sahelian area over $1559 \mathrm{~km}^{2}$ in Burkina Faso (Figure 1). The climate of the site is characterized by two 
highly contrasting seasons, the dry season and the rainy season. The dry season from October to June includes a cold period $\left(14^{\circ} \mathrm{C}\right.$ to $\left.36^{\circ} \mathrm{C}\right)$ from October to February and a hot dry season from March to May/June with extreme temperatures above $40^{\circ} \mathrm{C}$ in April/May. The rainy season has annual precipitation ranging from 400 to $600 \mathrm{~mm}$ (CRB, 2013). During this period, the number of rainy days and precipitation in the region are characterized by high interannual and spatio-temporal variability.

The vegetation on the site is generally shrubby savannah type with a continuous herbaceous mat. The savannah is made up of shrubs. The woody stratum is mainly dominated by thorny trees such as Acacia raddiana, Acacia laeta, Acacia nilotica, Acacia seyal, Acacia macrostachya, Balanites aegyptiaca and non-thorny trees such as Combretum micranthum, Combretum aculeatum, Guiera senegalensis, Piliostigma reticulatum. As for the herbaceous mat, it is dominated by annual grasses with low bromatological value such as Loudetia togoensis, Aristida spp. and more Schoenfeldia gracilis.

The main activities of the populations residing in the study site are agriculture, livestock and trade with a dominance of livestock activities. The main species of domestic animals reared are cattle, sheep and goats.

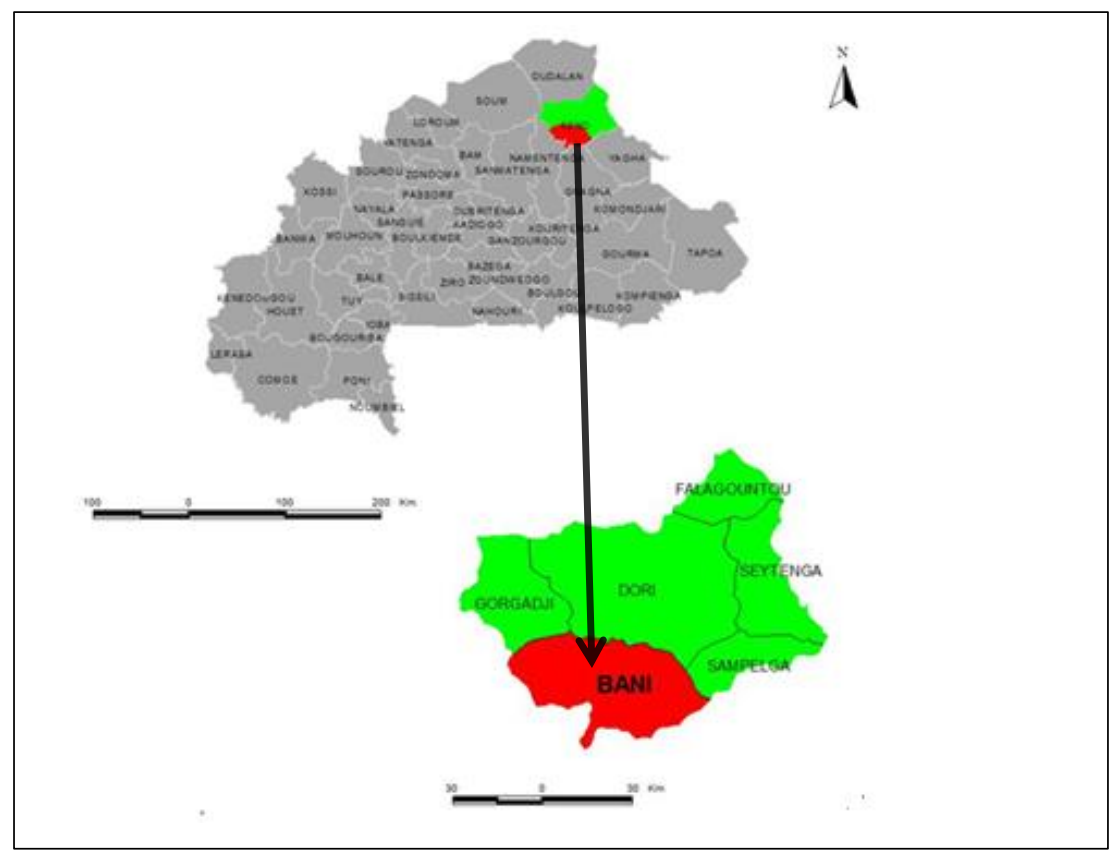

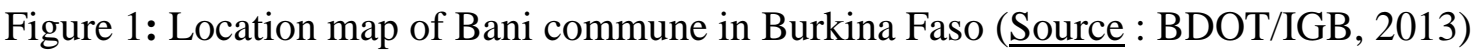

\section{Methodology}

For this study, primary and secondary data were collected before being cross-referenced for possible comparisons to better assess the perception of the farmers surveyed (West et al. 2008; Lema and Majule, 2009). To this end, primary data were collected from 143 randomly selected farmers and subjected to individual single-pass interviews in the field using a questionnaire from July to October 2017. The information collected related to the socio-economic characteristics of the respondents, constraints in agriculture and livestock, different aspects of the perception of the 
impact of climate change, endogenous adaptation strategies as well as the different income options of the actors in the study area. As for the secondary data collected, they were related to the meteorological situation of the region, in particular rainfall, temperature and their evolution over the last twelve years (2005-2016). Since there is no weather station installed in the rural commune of Bani, data from the nearest weather station in Dori was used.

\section{Statistical Analyses}

Quantitative and qualitative data collected were used for descriptive statistical analyses (means, percentages and frequency). StatView software was used to compare the parameters measured using the Chi-square test at 5\%. The Excel spreadsheet was also used to construct correlation curves and graphs.

\section{Results}

\section{Characteristics of Respondents and Main Activities}

Table 1 presents the socio-economic characteristics of the 143 respondents in 11 villages in the rural commune of Bani. These villages are Amsia (11.9\% surveyed), Bani-Tougouribé (8.4\%), Bayieldjaga (9.1\%), Bomboyel (11.2\%), Bouna (6.9\%), Dinalaye (6.9\%), Gangaol (7.7\%), Gorouol-Kadjé (11.2\%), Kallo (7.7\%), Wouro-Belko (10.5\%) and Wouro-Farouko (8.4\%). The respondents were men $(67.1 \%)$ and women $(32.9 \%)$ with an average age of $55.3 \pm 0.3$ years, $58.7 \%$ of whom were over 50 years of age. Less than half of these people (39.9\%) are literate, especially in Fulfuldè, the local language of the study area where the households surveyed have 2 to 14 people in their care.

Table 1: Socio-economic characteristics of the respondents in the study area

\begin{tabular}{|l|l|c|c|}
\hline Variables & Modalities & Frequencies & Percentages (\%) \\
\hline & Amsia & 17 & 11,9 \\
& Bani-tougouribé & 12 & 8,4 \\
& Bayieldjaga & 13 & 9,1 \\
& Bomboyel & 16 & 11,2 \\
& Bouna & 10 & 7 \\
Villages & Dinalaye & 10 & 7 \\
& Gangaol & 11 & 7,6 \\
& Gorouol-kadjé & 16 & 11,2 \\
& Kallo & 11 & 7,6 \\
& Wouro-Belko & 15 & 10,5 \\
& Wouro-Farouko & 12 & 8,4 \\
\hline Sex & Female & 47 & 32,9 \\
& Male & 96 & 67,1 \\
\hline Age & $<30$ years of age & 83 & 0 \\
& between 30 and 6 years old & 60 & 58,04 \\
& $\geq 50$ years old & 86 & 61,95 \\
\hline Education & Illiterate & 57 & 39,14 \\
& Literate & 52 & 36,36 \\
\hline Households & 0-1 person & 91 & 63,63 \\
& 2-14 & & \\
\hline
\end{tabular}




\begin{tabular}{|l|l|c|c|}
\hline Crop seeds & Local & 143 & 100 \\
& Improved & 25 & 17,5 \\
& Local and improved & 84 & 58,7 \\
\hline
\end{tabular}

The respondents are mainly agropastoralists (100\%). Agriculture is practiced to meet the food needs of their families on plots with an average area of $3.5 \pm 2.2$ ha using local (100\%) and improved $(58.7 \%)$ seeds. The main speculations cultivated in the plots are millet (Pennisetum glaucum [L.] R. Br.) (100\% of the respondents), sorghum (Sorghum bicolor [L.] Moench) (99.3\%), groundnuts (Arachis hypogea L.) (18.2\%) and maize (Zea mays L.) (17.5\%). In addition, the most frequent speculative associations are millet-sorghum $(99.3 \%$ of respondents), millet- peanuts $(18.2 \%)$ and millet- maize (17.5\%). Harvest residues from these crops are used to feed livestock, especially ruminants. The main constraints of the crops in the study area are the late start of rains (96.4\% of respondents), their irregularity and poor distribution (100\%), high winds $(91.7 \%)$ and high heat and locust outbreaks $(91.7 \%)$. In addition to these natural constraints, there are logistical and technical ones such as the lack of agricultural equipment (99.3\%), low soil fertility (72.7\%), the difficulty of obtaining improved seeds more adapted to current climatic conditions (60.1\%), the lack of manpower (46.2\%) and the insufficient assistance from the State authorities (12\%). Facing with these constraints, agropastoralists (54.54\%) are members of farmers' groups or associations that make it easier for them to obtain agricultural equipment through grants, partial payment of the cost of purchasing the equipment or warrantage. Farmers also sometimes benefit from training (recycling sessions) on farming techniques such as zaï, the construction of stone barriers, half-moons for water retention and the recycling of animal waste by building manure pits to produce organic manure to fertilize crop plots.

Livestock farming is practiced according to the sedentary system (99.3\%) with an average of 22.1 \pm 16.4 animals composed of $4.3 \pm 4.1$ cattle, $3.9 \pm 4.5$ sheep, $6.5 \pm 7.1$ goats, $6.8 \pm 11.1$ poultry and $1.2 \pm 0.7$ asses. Ruminants reared by the respondents are cattle and small ruminants (sheep and goats) composed of Sahelian breeds. There is also a massive introduction of other breeds from outside the study area. These breeds are the zebus of the Azawak and Goudali breeds, the sheep of the Bali-Bali and Balmi breeds and the goats of the red breeds of Maradi and Mossi. Ruminant breeding constraints are food, health, technical and financial. Indeed, all agropastoralists report the lack of fodder, natural pastures and watering facilities for animals. Drinking water for animals is a significant problem because existing sources of supply are defective and do not solve the problem of drinking water for people and animals. In addition to these problems, there are diseases (100\% of the people surveyed), particularly gastrointestinal parasites and high feed costs (98.6\%), which contribute to reducing the expression of animal productivity.

To minimize these problems, the seasonal timing of ruminant farming activities described in Table 2 is practiced by agropastoralists as endogenous solutions. In addition to these activities, agropastoralists use certain practices during the lean season, such as (i) sell animals (2 to 3) to buy concentrates in the form of livestock feed to ensure the survival of the rest of the herd, (ii) drill wells or boreholes $(99.3 \%)$ to meet the animals' water needs and (iii) use modern and traditional medicine $(100 \%)$ to treat their sick animals. 
Table 2: Seasonal schedule of livestock activities in the study area.

\begin{tabular}{|l|l|l|l|l|l|l|l|l|l|l|l|l|}
\hline \multirow{2}{*}{ Activities } & \multicolumn{9}{l|}{ Months of the year } \\
\hline & Jan & Feb & Mar & App & May & Jn & Jl & At & Sept. & Oct. & Nov. & Dec. \\
\hline $\begin{array}{l}\text { Exploitation of natural } \\
\text { pasture }\end{array}$ & & & & & & & & & & & & \\
\hline $\begin{array}{l}\text { Exploitation of forage woody } \\
\text { plants }\end{array}$ & & & & & & & & & & & \\
\hline $\begin{array}{l}\text { Mowing and conservation of } \\
\text { natural fodder }\end{array}$ & & & & & & & & & & & \\
\hline Storage of crop residues & & & & & & & & & & & \\
\hline Animal fattening practice & & & & & & & & & & & & \\
\hline $\begin{array}{l}\text { Marketing of fattened } \\
\text { animals }\end{array}$ & & & & & & & & & & & & \\
\hline Animal vaccination & & & & & & & & & & & & \\
\hline
\end{tabular}

\section{Perception on Climate Change}

The perception of respondents on climate change in our study was analysed in terms of the nature of rainfall and temperature.

For rainfall, almost all (96\%) of the people surveyed noted a decrease in the quantity of annual rainfall and the number of rainy days per year, which leads to a shortening of the winter season. Similarly, the results of the analysis of rainfall meteorological data from 2005 to 2016 show a decrease in rainfall amounts (Figure 2) and a correlation curve with a coefficient of variation of about -1.9. On the other hand, the assertions of the respondents on the number of rainy days per year seem less true with regard to the results of the analysis of meteorological data on the number of rainy days in Figure 3 or the coefficient of variation of the correlation curve is 0.2 .

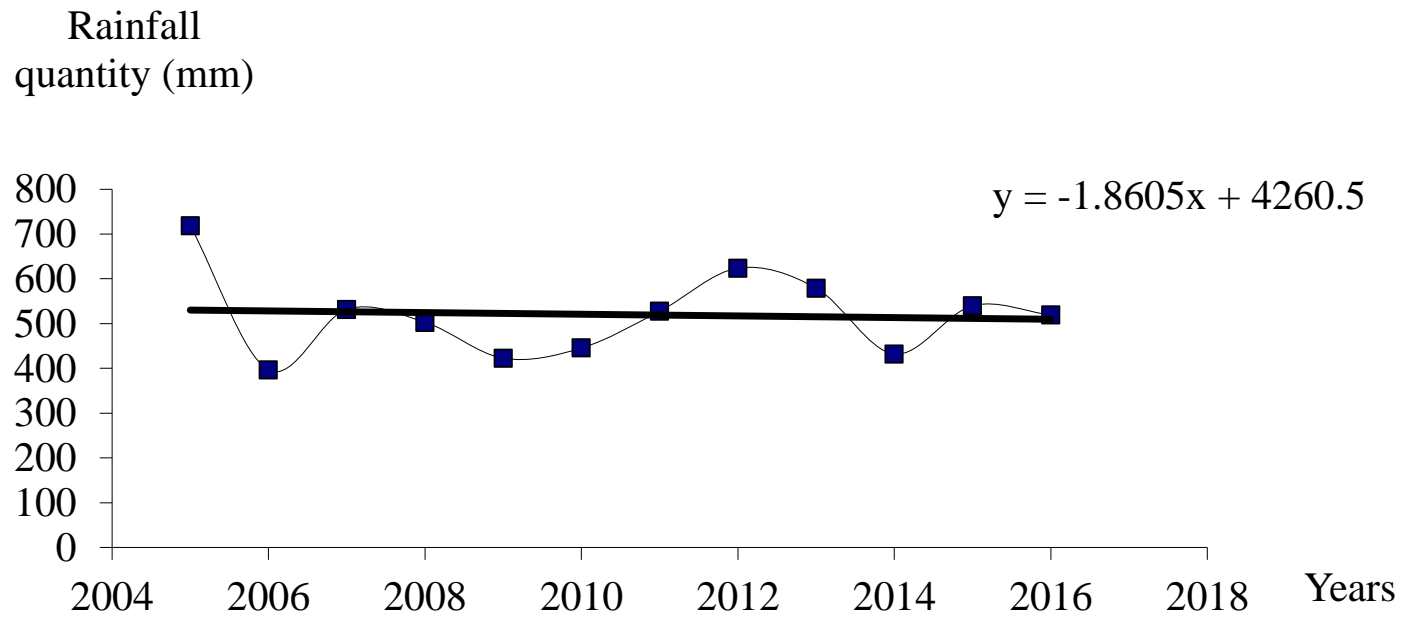

Figure 2: Evolution of average rainfall from 2005 to 2016 


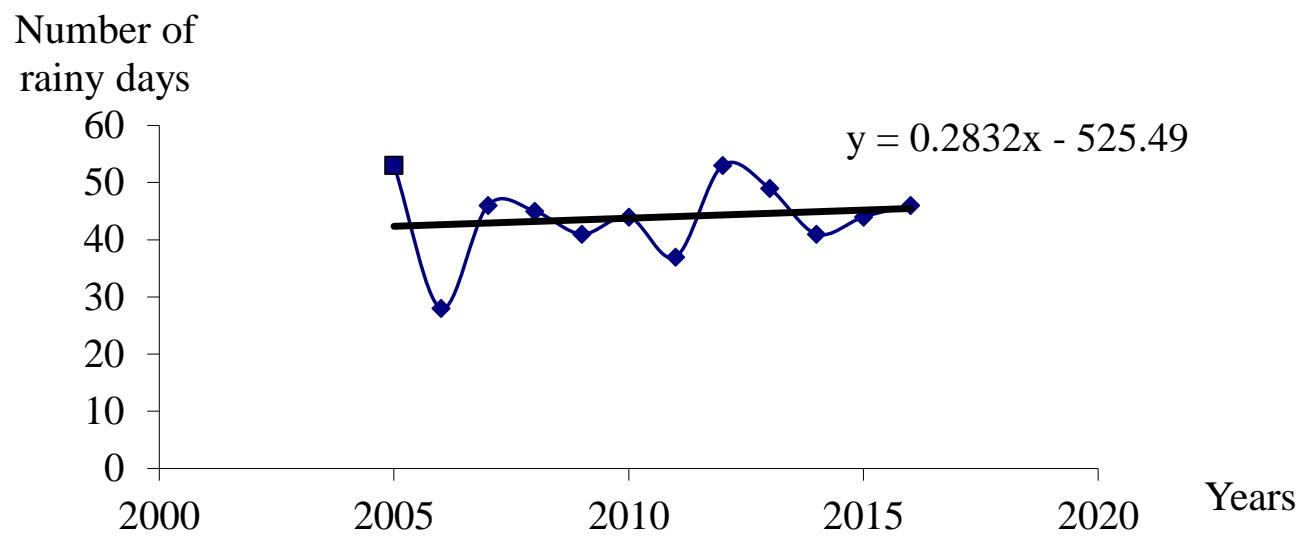

Figure 3: Evolution of the number of rainy days from 2005 to 2016

As for temperature, $91.7 \%$ of the people surveyed perceive an increase in annual temperatures and find that the duration of hot periods is becoming longer and longer. The results of meteorological data for temperatures from 2005 to 2016 show a general upward trend over the last twelve years with correlation curves showing positive coefficients of variation (Figure 4).

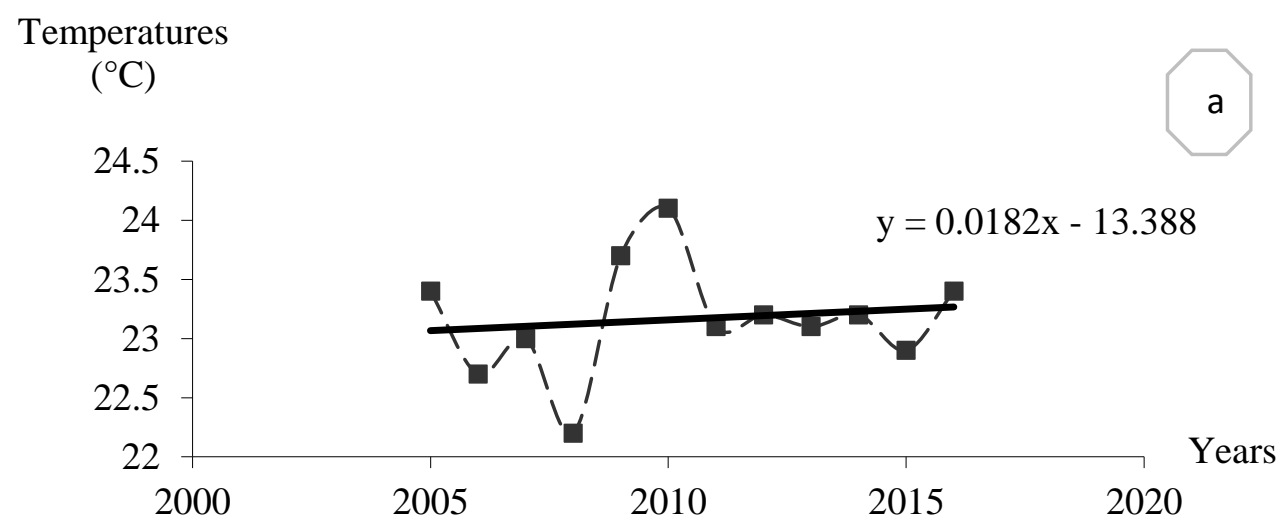

Temperatures

$\left({ }^{\circ} \mathrm{C}\right)$

b

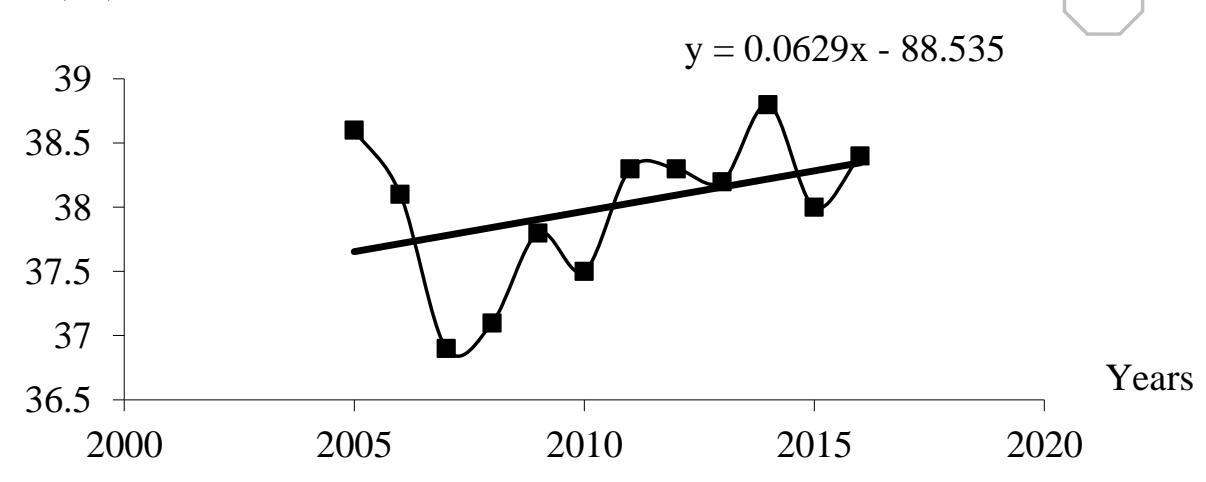




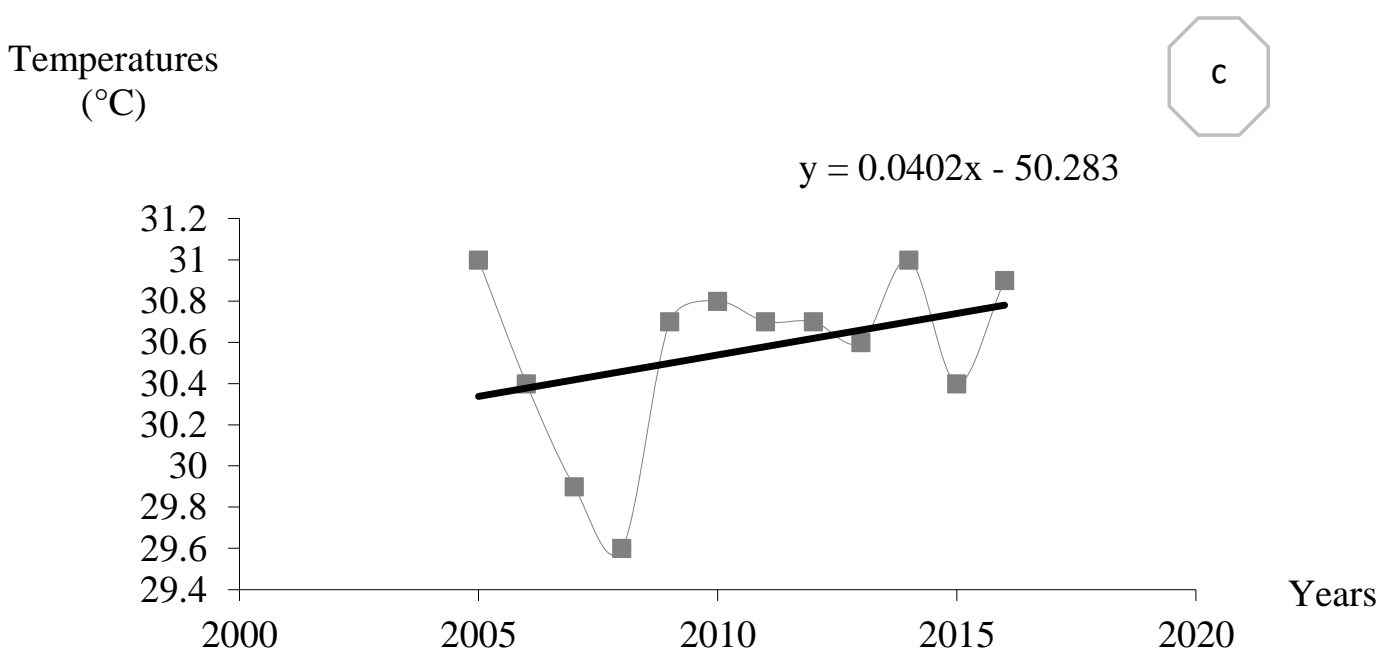

Figure 4: Temperature evolution from 2005 to 2016

(a: minimum temperatures, b: maximum temperatures, c: average temperatures)

\section{Findings of the Respondents}

One of the direct consequences of the variability in rainfall and temperature perceived by rural populations is generally its impact on the availability of pastoral resources. In our study environment, $100 \%$ of people notice that this availability is strongly affected, with a decrease in the availability of herbaceous plants. Similarly, they report that the woody and crop residues that constitute supplemental forage during the lean season are increasingly insufficient. In addition, $92 \%$ of the people surveyed note that water availability is decreasing, thus accentuating the watering difficulties of humans and animals in the dry season.

The people surveyed believe that the natural resources essential for ruminant breeding are in sharp decline due to demographic pressure and especially the fluctuation of climatic parameters.

\section{Endogenous Adaptation Solutions}

Faced with the constantly changing climatic situation in the study area over the past twelve years, the surveyed population has adopted practices of diversifying agro-sylvo-pastoral production activities and other activities to survive (Figure 5). The most common activities are agriculture through the creation of stony ridges (97.3\%), the use of seeds of improved varieties (58.7\%) and market gardening followed by livestock farming through the practice of fattening $(88.4 \%)$, forestry through tree planting (39.4\%) and the prohibition of excessive logging (52.6\%), gold panning $(44.5 \%)$ and small-scale trade $(25.1 \%)$. 


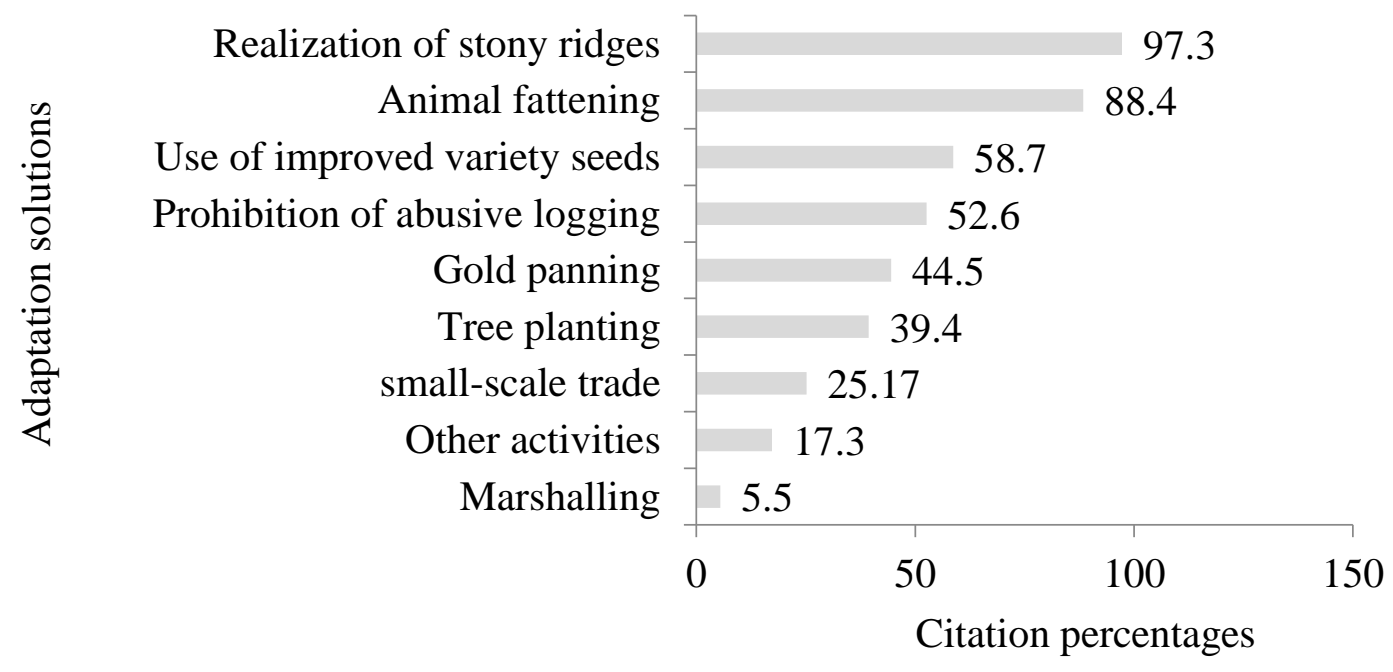

Figure 5: Main adaptation activities applied in the study environment by respondents

\section{Discussions}

The populations of the rural commune of Bani in the Sahel region of Burkina Faso have a good knowledge of climate change. They perceive it through a decrease in rainfall, an increase in temperatures and an increased decrease in agro-sylvo-pastoral production in recent years. Similar results are reported by authors such as Maddison (2006), Majule et al. (2008) and Lema and Majule (2009) who state that many African producers perceive a decrease in rainfall with high interannual variability and rising temperatures. The perceptions of the respondents are corroborated by the analysis of meteorological data which showed a downward trend in rainfall with an increase in deficit years and an upward trend in temperatures over the last twelve years. This analysis confirms that of the PANA expert group (2003), which concluded that Burkina Faso's average rainfall has fallen significantly, and temperature has risen significantly throughout the country. The perception of the respondents on the evolution of rainfall is therefore not limited to the water level and the difference in rainfall between years because they also perceive a decrease in the quantity of rainfall and the length of the winter season. However, predictions of total precipitation volume do not always capture the impacts of climate variability because factors such as the timing of the first rains, their spatial and temporal distribution during the season and their effectiveness are also criteria that influence their activities (Simms, 2005). Thus, in addition to the decrease in water levels, the respondents note that the winter season is becoming increasingly shorter and is settling late, leading to an extension of the dry season. They have the impression that the climate is getting warmer and the rains are less predictable and of short duration. Studies conducted under climatic conditions close to and similar to those of our study site have yielded similar results (West et $a l$., 2008; Wongtschowski et al., 2009).

In addition, the results of the study show that rainfall is highly variable. This situation is characteristic of the study site, which is located in the Sahel region. According to Hulme (2001), rainfall in Sahelian countries has increased since 1990 compared to the long years of drought from 1960 to 1990 . However, this increase remains variable in the space of these countries as shown by the decrease observed in the site of our study. 
The evolution of the measured variables also influences the availability of pastoral resources in our study. Indeed, all respondents (100\%) noticed the clear decline in natural fodder and water resources over the years. As the productivity of natural pastures is highly dependent on rainfall but also on temperature conditions, the decrease in rainfall leads to a reduction in these pastures that can be used by livestock (Lema and Majule, 2009). As for the increase in temperatures, it stimulates evaporation, plant evapotranspiration and increases the probability of severe droughts (IPCC, 2007). Natural plant species of good forage value, particularly perennial grasses and some woody fodder species disappear with insufficient rainfall and repeated droughts. The consequent consequence on the soil is a decrease in the pastoral value of pastures, especially in the dry season from November to June. This perception of the respondents of the impact of climate change on pastoral resources is similar to that reported by Wongtschowski et al., (2009). Indeed, these authors report that in Niger, producers are seeing a reduction in natural pastures, soil degradation, desertification and forest loss, a decrease in woody and herbaceous species and insufficient natural regeneration under the influence of climate change.

In the study, the respondents try to adapt their agro-sylvo-pastoral practices to changing climatic conditions in order to reduce their impact on livestock and crops. The most common practices encountered in households are the diversification of production and activities. These practices seem to be gradually abandoning livestock mobility, particularly large transhumance, in favour of sedentarisation combined with small transhumance linked to the number of ruminants kept. As for agriculture, its practice is characterized by a low level of equipment for producers, a total dependence on random rainfall, soil degradation and a low level of fertilizer use. Animal traction is also rarely used in the area, which is somewhat paradoxical given the significant number of cattle in the households of the persons surveyed. This situation would explain the low food production and, consequently, the increased vulnerability of the surveyed population to food insecurity and poverty.

Small ruminants play an important role in livestock systems and enable livestock farmers to meet their spontaneous social and economic needs. Their higher numbers in the study area could be explained by the fact that sheep and goats would be better able to withstand less favourable climatic conditions than cattle. They also constitute a monetary asset accessible at any time and the increase in their breeding would be a response to the progressive monetarization of livestock (Malonine, 2006) to fight poverty in the study environment.

Diversification of activities through crop production allows pastoralists to meet their consumption needs and to dispose of crop residues such as fodder to feed animals and to produce organic manure for crop soils. Despite the government's efforts to popularize seeds of improved varieties, their use at the level of the farm households surveyed remains low. Actions supported and adapted to the use of seeds of improved crop varieties should be carried out by the State and private structures operating in the region with a view to improving the yields of sown crops.

The study thus reveals the importance of diversification of development activities by the populations residing in the Sahel region of the country in general and in our study environment in particular. Nori et al. (2008) therefore rightly note that the diversification of actions is presented as a strategy for adapting to climate hazards in Sahelian pastoral systems. This behaviour could be explained by the low availability of natural resources for livestock in our study environment where 
resources are extremely scarce in quantity and quality, leading pastoralists to become almost exclusive farmers. This observation is motivated by the fact that mobility is not practiced by the people surveyed in our study, whereas it is an ancient practice specific to Sahelian communities as an adaptation response to climate instability (Kgosikoma, 2006). Indeed, mobility seen from the perspective of large transhumance as previously practiced by the populations of the area tends to be replaced by small transhumance. This behaviour could be explained by the low number of ruminants kept in households, conflicts between farmers and herders due to the lack of animal corridors associated with a gradual degradation of natural pastures in host areas.

With regard to the exploitation of woody trees, the results of the analysis of the data collected reveal that the exploitation of forest products plays an important role for the population surveyed. This activity is done in the form of picking and carried out in a traditional setting. The products exploited are leaves, fruits and seeds or kernels of various natural plant species. These species include Acacia senegal and Acacia seyal for gum arabic, Balanites aegyptiaca, Zizyphus mauritiana, Tamarindus indica, Adansonia digitata for monkey bread, Hyphaene thebaica for multiple uses.

Similarly, there are orchards of guava trees, lemon trees and mango trees. All these wood products are in high demand from the populations of the surrounding large cities. Consequently, if their various productions are better managed and organized, they could constitute interesting sources of income for the population.

Gold panning by the respondents has distant causes due to the droughts of 1973 and 1984 and the locust invasions of 1974 and 1975 in the study area. These natural disasters have destroyed crops and positioned gold panning as a relief activity for farmers, with the aim of generating income to buy basic food supplies. The various gold panning sites are currently located in the villages of Bayieldjaga, Gangaol, Babirka, Diouga, Gorouol-Kadjé, Bindéré, Bani, Modjouma of the rural commune of Bani. These sites are operated using traditional methods by $44.1 \%$ of the people surveyed. No mining company is directly involved in the supervision or monitoring of these sites. However, the resulting production is marketed through local intermediaries of some mining companies.

The trade practiced in the study environment is greatly influenced by that of the major centers of the surrounding cities (Ouagadougou, Kaya and Dori). It is undergoing an evolution, especially the sale of livestock followed by cereals, artisanal products and various commodities (oil, sugar, salt, flour, etc.). Livestock, including ruminants, are sold at the permanent livestock markets in Bani, Gangaol, Dinalaye, Lamdamol and Gorouol-Kadje, which are held every three days.

\section{Conclusions}

The study reveals that respondents perceive climate change through rainfall and temperature variation. The variation in these climatic parameters affects the availability of natural and cultivated pastoral resources (crop residues), leading to a decrease in the productivity of natural pasture and water resources. To cope with this situation, the respondents have developed strategies to diversify their activities and adapt their past production practices. The breeding of small ruminants, traditionally conducted in support of cattle, is becoming increasingly important in view 
of their ability to adapt to climatic conditions and their increasing number in the households surveyed. All these practices allow populations to minimize the effects of climate change on their activities for their survival in the environment. To better assess the perception of the populations surveyed, studies taking into account pastoral indicators related to the evolution of forage species, water points and the productivity of pastures and herds will have to be carried out. The analysis of these parameters will allow pastoralists to better perceive the quantitative and qualitative changes in the natural pastoral resources of the environment in relation to climate change. These studies will thus enable public and private structures involved in development to improve endogenous strategies developed by local populations to face the challenge of current and future climate change.

\section{References}

[1] Commune rurale de Bani (CRB), 2013. Plan communal de Bani 2014-2018. Rapport final. CEFCOD Sarl et PNGT. Province du Seno. 82 pages.

[2] Hermann S. M., Hutchinson C. F., 2005. The changing contexts of the desertification debate. Journal of Arid Environments, 63: 685-699

[3] Hulme, M., Doherty, R., Ngara, T., New, M. and Lister, D. 2001. African climate change: 19002100.cliamte research 17, 145-168.

[4] IPCC, 2007. The Physical Science Basis: summary for Policy Makers. IPCC Geneva

[5] Hermann S. M., Hutchinson C. F., 2005. The changing contexts of the desertification debate. Journal of Arid Environments, 63: 685-699.

[6] Kagoné A, 2004. L'élevage des petits ruminants au Burkina Faso: état des lieux et politique de développement. 9 pages

[7] Kgosikoma O. E., 2006. Effect of climate variability on livestock population Dynamics and Community Drought management in Kgalagadi, Botswana. Thesis of degree of Master's of Sciences in Management of Natural Ressources and Sustainable Agriculture. Norwegian University of Life Sciences, Department of International Environment and development Studies (NORAGIC), 66 pages.

[8] Lema M. A., Majule A. E., 2009. Impacts of climate change, variability and adaptation strategies on agriculture in semi-arid areas of Tanzania: The case of Manyoni District in Singida Region, Tanzania. African Journal of Environmental Science and Technology Vol. 3 (8): 206-218.

[9] Maddison D., 2006. The perception of and adaptation to climate change in Africa CEEPA Discussion Paper $\mathrm{N}^{\circ} 10$. Special Series on Climate Change and Agriculture in Africa.

[10] Malonine C., 2006. Les liens famille-troupeau du Ferlo (Sénégal): témoins de la dynamique des systèmes d'élevage pastoraux. Thèse de doctorat. Université Claude Bernard de Lyon (MédecinePharmacie), 101 pages.

[11] Ministère des Ressources Animales, 2009. Politique de Développement de l'Elevage au Burkina Faso 2010-2020, 40 pages.

[12] Ministère des Ressources Animales, 2014.Direction Générale des Etudes Statistiques et Sectorielles, annuaires 2014 des statistiques de l'élevage, 177 pages.

[13] Ministère des Ressources Animales/ Direction des Etudes et de la Planification (MRA/DEP), 2006. Les statistiques du secteur de l'élevage au Burkina Faso. Ouagadougou. 70 pages.

[14] Nori M., Taylor M., Sensi A., 2008. Droits pastoraux, modes de vie et adaptation au changement climatique. iied, Dossier $n^{\circ} 148,20$ pages.

[15] Secrétariat Permanent du Conseil National de l'Environnement et du Développement Durable (SP / CONEDD), Groupe d'experts PANA du Burkina Faso, 2003. Synthèse des études de vulnérabilité et d'adaptation aux changements climatiques : étude de cas du Burkina Faso. Etapes 3, 4 et 5 du 
processus NAPA. Atelier de formation sur les PANA, Ministère de l'Environnement et du Cadre de vie, Ouagadougou. 96 pages

[16] West, C. T., Roncoli, C., \& Ouattara, F., 2008. Local perceptions and regional climate trends on the Central Plateau of Burkina Faso. Land Degradation \& Development, 19(3), 289-304. doi:10.1002/ldr.842

[17] Wongtschowski M., Verburg M., Waters-Bayer A., 2009. What can local innovation contribute to adaptation to climate change? Paper to be presented and discussed at the $3^{\text {rd }}$ International Conference on Community-Based Adaptation, Dhaka, Bangladesh

*Corresponding author.

E-mail address: ade1_bf@ yahoo.fr 